\title{
Variolation, Vaccination and Popular Resistance in Early Colonial South India
}

\author{
NIELS BRIMNES*
}

The campaigns to prevent smallpox in the eighteenth and nineteenth centuries are commonly understood as the first attempts of large-scale state-sponsored medical intervention in society as such. ${ }^{1}$ Before the discovery of the cowpox vaccine inoculation with variolous matter-known as variolation-was the most widespread preventive against the disease. This practice was well established in parts of Asia and introduced to Europe by Mary Wortley Montagu from Constantinople in $1721 .^{2}$ While variolation achieved some popularity_particularly in Britain-Edward Jenner's discovery of the cowpox vaccine in 1796 intensified the efforts to combat smallpox, and vaccination was introduced to large parts of the world within a few years. Although the spread of immunization against smallpox is commonly described as highly successful, the campaigns also represented an early encounter between an elitist state-sponsored medicine and various forms of popular resistance. ${ }^{3}$

In India the notion of popular resistance to smallpox prevention took a particular turn because variolation was well established in some regions — most notably Bengal — and here came to represent a rival and not obviously inferior practice to vaccination. ${ }^{4}$ Based on the study of such regions, the history of smallpox prevention in colonial India is often seen as consisting of two phases. Initially, the British looked with sympathy and even admiration on the "popular" Indian practice of variolation, but after the advent of vaccination they grew increasingly hostile and by the mid-nineteenth century variolation was described as "a murderous trade". ${ }^{5}$ In this article I offer a study of smallpox prevention in early colonial south India, the Madras Presidency; one of the regions where variolation was virtually unknown. This again altered the context in which popular reactions to smallpox prevention were articulated. Most notably, the campaign against smallpox in south India began as a deliberate attempt to introduce and promote variolation.

*Niels Brimnes, PhD, Department of History, Aarhus University, DK-8000 Aarhus C, Denmark.

Research for this article was conducted with financial support from The Danish Research Council for the Humanities. I am particularly grateful to Clare Hall College, Cambridge, for granting me a three-month visiting fellowship in 2001, and to the staff at the Tamil Nadu State Archives in Chennai for friendly advice.

${ }^{1}$ F F Cartwright, A social history of medicine, London, Longman, 1977, p. 92; Claudia Huerkamp, 'The history of smallpox vaccination in Germany: a first step in the medicalization of the general public', J. contemp. Hist., 1985, 20: 617-35, p. 617.

${ }^{2}$ While variolation might have been practised on the fringes of European society, it was perceived as an "Eastern" practice in the eighteenth century. For references to long-standing variolation in Wales and Scotland, see J Kirkpatrick, The analysis of inoculation, comprising the history, theory, and practice of it, London, J Buckland, 1761, pp. 184-5. P Razzell, The conquest of smallpox, Firle, Caliban Books, 1977, p. 1.

${ }^{3}$ Huerkamp, op. cit., note 1 above, p. 617. I shall use "immunization" to describe both variolation and vaccination, while "inoculation" refers only to the technique of variolation.

${ }^{4}$ Paul R Greenough, 'Variolation and vaccination in South Asia $c .1700-1865$ : a preliminary note', Soc. Sci. Med., 1980, 14D: 345-47.

${ }^{5}$ David Arnold, Colonizing the body: state medicine and epidemic disease in nineteenth-century India, Berkeley, University of California Press, 1993, p. 138 


\section{Niels Brimnes}

As in Europe, popular reactions to smallpox prevention in India were often conceptualized as "resistance" and seen as an expression of irrationality and superstition. Whether in India or in Europe the campaigns to prevent the disease entailed a notion of "difference" between benevolent medicine and popular belief. It can be argued, however, that in India this notion of difference intersected with attempts to construct a more general notion of "otherness" between colonialist Europeans and their Indian subjects. While the rhetoric accompanying the campaigns against smallpox can easily be seen as a contribution to this general vision of Indian society, this article argues that, even when colonial power and European medicine joined forces against the alleged prejudices of the Indian population, ambiguity could not be eliminated. In at least two instances the colonial authorities in Madras were unable to apply a simple understanding of Indian society as superstitiously opposed to European medicine. First, as the colonial authorities launched their campaign against smallpox with the promotion of variolation, it was not possible to ignore the fact that variolation had stronger roots in India than in Europe, or that Europeans had actually adopted the practice from Asians. Second, any attempt to combat smallpox in India necessarily relied on Indian agents and the colonial authorities had to accept that at least some Indians were capable of fulfilling the crucial position as immunizers. In these two cases the colonial authorities had to concede to Indians an ambiguous position in which they did not merely represent stubborn resistance to western medical benevolence. ${ }^{6}$

\section{Combating Smallpox in Early Colonial South India}

Before 1800 the efforts to prevent smallpox in the British controlled parts of south India were at best sporadic. As the cowpox vaccine had not yet reached India, variolation was the only way to provide some protection against the disease. Variolation was a well-known and widespread technique in parts of northern and eastern India, but it was much rarer in the areas subject to the government of Madras. ${ }^{7}$ In the northernmost parts of the presidency "Woodiah" (Oriya) Brahmans were reported to have been practising variolation since "time immemorial"; the standard colonial phrase for established usage with an unidentifiable origin. ${ }^{8}$ Around 1800 indigenous inoculators were reported to be active in Vizagapatam District, although the collector stated that "the villagers are averse to inoculation unless the Small Pox should commit serious ravages on the population of a Village, when they call in the Assistance of one of the Inoculators". 9 Further south in Guntur

\footnotetext{
${ }^{6}$ Gyan Prakash has recently argued that the simple dichotomy of dominance versus resistance does not apply to the creation of difference in colonial India, not even in "scientific" areas. Gyan Prakash, Another reason: science and the imagination of modern India, Princeton University Press, 1999, pp. 19-20.

${ }^{7}$ Arnold, op. cit., note 5 above, p. 130. Arnold concludes that variolation was widespread in Bengal, Assam, Bihar and Orissa. It was also common around Varanasi (Benares), in parts of Punjab, in Rajasthan, Sindh, Gujarat and in scattered parts of Maharashtra and central India.

${ }^{8}$ The Brahmans themselves were equally unclear about the introduction of variolation in the area.
}

See a statement from four "Woodiah" Brahmans in British Library, Oriental and India Office Collections (hereafter BL-OIOC) F/4/96, Board's Collections no. 1953, fols 84-8. One observer claimed that variolation was practised by the Brahmans among the Worriahs, a brave, handsome, but less civilized tribe from the interior of the northern part of the Madras Presidency. Whitelaw Ainslie, 'Observations respecting the small-pox and inoculation in eastern countries; with some account of the introduction of vaccination into India', Trans. R. Asiatic Soc. Great Britain and Ireland, 1830, 2: 52-73, p. 63.

${ }^{9}$ BL-OIOC F/4/96, Board's Collections no. 1953, fol. 84 . 


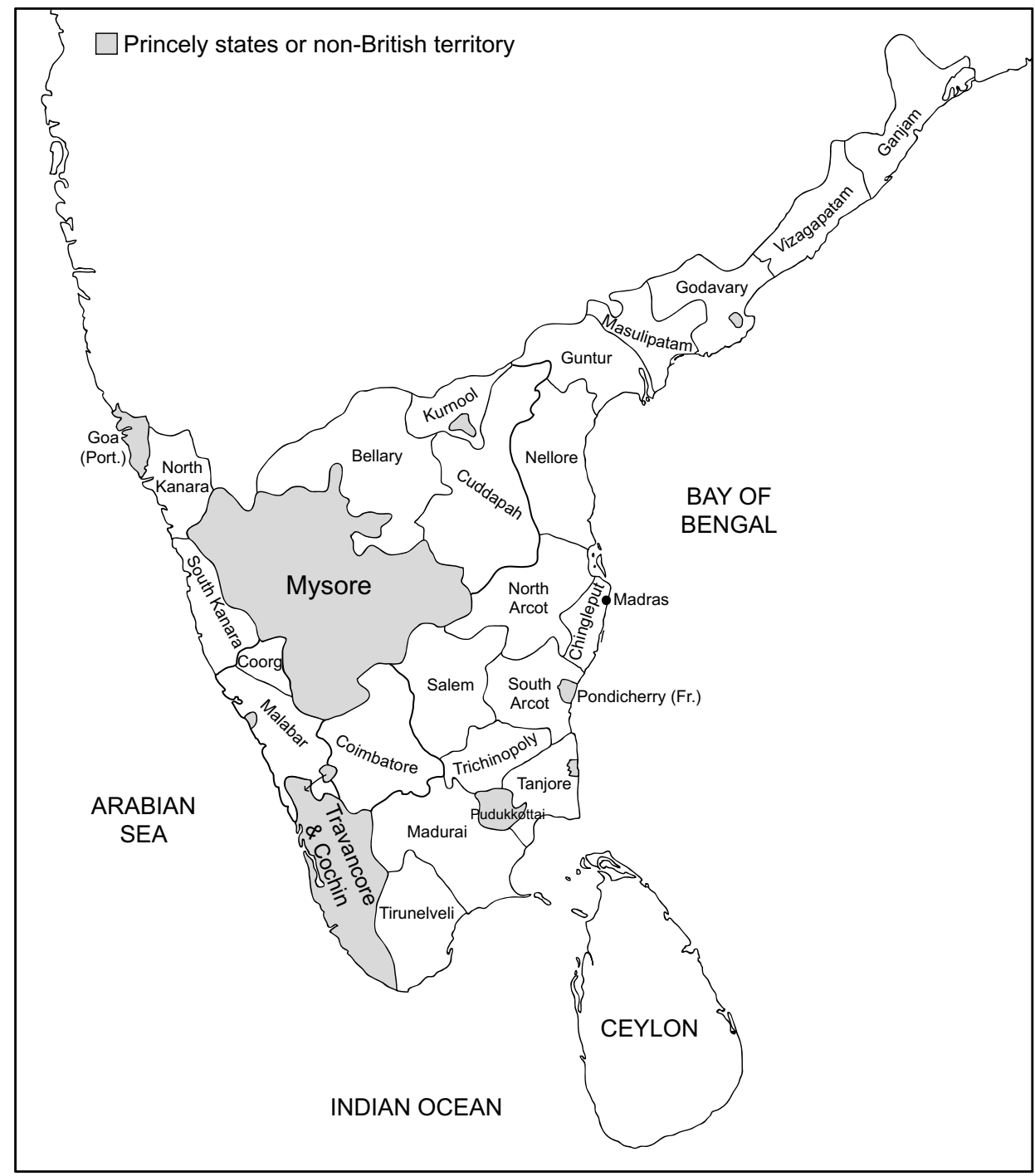

Figure 1: The Madras Presidency in the early nineteenth century, showing district boundaries. 


\section{Niels Brimnes}

District, the pioneer was the Zamindar of Chintapilly, who had been inoculated by a British surgeon in 1793 and subsequently employed his own indigenous inoculators. ${ }^{10}$

In the southern part of the Presidency, the earliest efforts to combat smallpox were centred around the military headquarters in Trichinopoly. By contrast to the northern districts, no indigenous inoculators were operating in the area and variolation was conducted exclusively on British initiative. The earliest specific reference to variolation in the territories subject to Madras came from Trichinopoly in 1787 when it was reported that Surgeon Nicol Mein had inoculated about twenty European soldiers. When news of Mein's achievement reached Madras in December 1787, a General Order was immediately issued recommending inoculation to all soldiers who had not had the disease. This order indicates that the technique of variolation was generally mastered by the surgeons attached to the East India Company's army. ${ }^{11}$ It appears that Mein in January 1788 inoculated children of European officers and a few sepoys, and this caused him to declare optimistically that he did "not despair of being able to introduce the practice among the natives, \& especially the Sepoys". ${ }^{12}$ It was, however, not until 1800 that substantial progress was made around Trichinopoly. Head Surgeon Richardson reported that he had inoculated 225 persons, which was an unusual achievement at the time. ${ }^{13}$ In Madras itself there is evidence that a group of European soldiers stationed at Mount St Thomas were inoculated as early as 1788, and in 1794 inoculation of the boys at the Male Asylum seems to have been well established. ${ }^{14}$

Encouraged by these scattered attempts, the government of Madras decided in September 1800 to launch a campaign to encourage variolation. According to government rhetoric, the campaign was not limited to the troops in the Company's army, but explicitly directed towards the civil population. Extracts from the colonial records were published in Arabic, Telugu and Tamil, medical officers were encouraged to follow the example set by Richardson, and collectors were told to assist in convincing the population of the benefits of variolation. ${ }^{15}$ Richardson was rewarded 500 pagodas for his efforts, while the Zamindar of Chintapilly received a mark of "particular Appropriation" from the governor. ${ }^{16}$ In April 1801, after the first "cold" season of the campaign — the period from December to March in which it was thought advisable to conduct variolation-475 persons were listed as inoculated. ${ }^{17}$ This figure was probably incomplete, as it did not include persons inoculated by indigenous inoculators based in Guntur District, who worked more independently of the colonial authorities. In August 1802 the government claimed that more than 26,000

${ }^{10}$ Ibid., fols $15,41$.

${ }^{11}$ BL-OIOC, P/252/20, Madras Military and Secret Proceedings, 16 and 24 Dec. 1787, fols 1392-3, 1546-9. Tamil Nadu State Archive, Chennai (hereafter TNSA), Surgeon General's Records (hereafter SGR) vol. 1, fols 193-4, 202-3, 210-11. TNSA, Military Department: General Orders vol. 7, fols 44-5. In Kanara, on the western coast of the peninsula, variolation was also introduced on British initiative (presumably from Bombay) in the 1780s. Sumit Guha, Health and population in South Asia: from earliest times to the present, London, Hurst, 2001, p. 141.

${ }^{12}$ TNSA, SGR vol. 3, fols $15-17$, and vol. 4, fols $5,12-14$.

${ }^{13}$ TNSA, SGR vol. 12, fols 179-80. BL-OIOC, F/4/96 no. 1953 Board's Collections, fols 5-6.

\footnotetext{
${ }^{14}$ TNSA, SGR vol. 4, fol. 3 and vol. 10, fols $41-6$.

${ }^{15}$ BL-OIOC F/4/96, Board's Collections no. 1953, fols 11-12, 15. TNSA, SGR vol. 12, fols $237-8$.

${ }^{16}$ BL-OIOC F/4/96, Board's Collections no. 1953, fols 2, 105-9. Pagoda was the current gold coin of the Coromandel Coast in the eighteenth century. 1 pagoda was worth approximately 9 shillings or $3 \frac{1}{2}$ rupees.

${ }^{17}$ Proceedings of the Medical Board, 6 Apr. 1801, entered in: TNSA, Madurai District Records (District Records appears hereafter as DR) vol. 1181, fols 267-8.
} 


\section{Variolation, Vaccination and Popular Resistance in South India}

persons had been inoculated in the years 1800, 1801 and 1802. Of these not less than 18,000 were from Guntur District and nearly 5,000 from Masulipatam. This made the area around the mouth of the river Krishna by far the most successful in the campaign and the Medical Board even suggested that inoculators be imported from these areas to remedy a shortage of inoculators near Madras. ${ }^{18}$ The districts of Guntur and Masulipatam were probably so successful because in this area variolation was conducted partly by indigenous agents backed by at least one influential indigenous magnate.

The enthusiasm for variolation within the colonial administration was, however, shortlived. Late in 1802 the cowpox vaccine reached Madras and the government immediately redirected its campaign to promote vaccination instead of variolation. ${ }^{19}$ From being conceptualized as a beneficial medical practice, variolation began to be seen in terms of inferiority. In September 1802, when rumour had it that the cowpox vaccine was as near as Hyderabad and Colombo, the Medical Board declared that vaccination with cowpox "affords in a very particular manner, by not being communicable otherwise than by actual insertion, many great and seemingly established advantages over the inoculated smallpox". ${ }^{20}$ Vaccination was seen as preferable to variolation, mainly because the latter was believed to cause occasional outbreaks of smallpox. Vaccination, on the other hand, was less reliable. In a rare reference to continued use of variolation after the introduction of the cowpox vaccine, Richardson suggested that this was due to "the many failures at the Commencement of Cow-Pock inoculation and the facility with which the [variolous] infection was always given". ${ }^{21}$ The practice of vaccination seems to have been less dependent on the relatively short "cold season", but it also introduced the danger of losing the vaccine potency. ${ }^{22}$ A final but important feature of vaccination was that it was a purely European technique and thus enabled the colonial authorities to conceive their campaign more explicitly as a contest between European benevolence and indigenous prejudice.

In January 1803 a plan for the diffusion of vaccination was published, which clearly intensified the campaign. One of the important features of the plan was that indigenous

\footnotetext{
${ }^{18}$ TNSA, SGR vol. 13A, fols 446,487 . The lack of inoculators around Madras became apparent in the summer of 1802 during an outbreak of smallpox in the "Black Town", the crowded indigenous suburbs immediately outside Fort St George.

${ }^{19}$ A letter from the government to the Medical Board, dated 23 Dec. 1802, in which they enquire about the quality of the "Cow Pox lately introduced" indicates the arrival of the vaccine at Madras. BL-OIOC F/4/153, Board's Collections no. 2613, fols 31-2. The vaccine might have arrived a few months earlier. Dominik Wujastyk writes that a boy was vaccinated and sent from Madras to Calcutta in October. Dominik Wujastyk, "“A pious fraud": the Indian claims for pre-Jennerian smallpox vaccination', in G J Meulenbeld and D Wujastyk (eds), Studies on Indian medical history, Groningen, Egbert Forsten, 1987, pp. 131-67, on p. 151.

${ }^{20}$ TNSA, SGR vol. 13A, fols 501-2.

${ }^{21}$ Proceedings of the Medical Board, 23 July 1804, entered with enclosures in: TNSA, Madurai DR vol. 1190 , fol. 167 . I only came across this reference
}

to the continued use of variolation in south India and it is perhaps surprising that this report came from the southern part where variolation was not established before the British introduced it. The unreliability of early vaccination has been noted by a number of scholars. Harish Naraindas, 'Care, welfare and treason: the advent of vaccination in the 19th century', Contributions to Indian Sociology, 1998, n.s. 32: 67-96, p. 70. S Bhattacharya,

M Harrison and M Worboys, Expunging variola: public health and the control and eradication of smallpox in India (forthcoming).

${ }^{22}$ Arnold emphasizes that vaccination had its season, too. However, the evidence treated here indicates vaccination activities outside the period from December to March. Arnold, op. cit., note 5 above, p. 140. Losing the vaccine potency was particularly unfortunate, because cowpox was rare, if not entirely absent in India. For the contemporary view that cowpox did not exist naturally in India, see Ainslie, op. cit., note 8 above, p. 66 . 


\section{Niels Brimnes}

Table 1

Geographical distribution of immunization 1800-1804

\begin{tabular}{lcc}
\hline Area & 1800-Aug. 1802 & Sept. 1802-April 1804 \\
\hline Northern Division & $* 4588$ & 2099 \\
Centre Division & $* * 18199$ & 25605 \\
Presidency (Town of Madras) & 23 & 29811 \\
Southern Division & 2302 & 56299 \\
Mysore Division & - & 27587 \\
Malabar Province & 859 & 4408 \\
Ceded Districts & - & 31 \\
Not identifiable & 425 & - \\
Total & 26396 & 145840 \\
\hline
\end{tabular}

*All inoculations conducted in Masulipatam District.

**All inoculations conducted in Guntur District.

The divisions referred to in the table are the divisions of the Madras Army (see Figure 2). The table from which the figures of the period 1802-4 has been computed displays minor inaccuracies. These are, however, all below 100 persons and thus not of any significance for the overall picture.

Sources: TNSA, SGR vol. 13A, fol. 446; Proceedings of the Medical Board, 23 July 1804, entered with enclosures in: TNSA, Madurai DR vol. 1190, fol. 166.

vaccinators were to be employed in a systematized way. They were to be instructed, certified, dispatched and then controlled by European surgeons stationed throughout the districts of the Presidency. ${ }^{23}$ The effects of the plan are clearly visible in the available vaccination statistics. In twenty months between September 1802 and April 1804, 145,000 persons were returned as vaccinated compared with 26,000 variolated in a period of approximately the same length between the autumn of 1800 and August 1802. ${ }^{24}$ These are impressive - presumably exaggerated - figures, and they were certainly far larger than in both contemporary Bombay and Bengal. ${ }^{25}$

The figures for the period after September 1802 also reveal that almost all the vaccinations were conducted in the central and southern parts of the Presidency, while they had virtually stopped in the northern part. This is surprising, because before 1803 variolation had been most successful to the north of Madras (see Table 1). It is possible that while even the limited presence of indigenous inoculators in the northern districts promoted the diffusion of variolation, the same presence inhibited the acceptance of the new and completely alien

${ }^{23}$ OIOC F/4/153, Board's Collections no. 2613, fols $42-3,60-3$. See also the government advertisement published on 19 Jan. 1803, fols 69-75 and fols 77-84.

${ }^{24}$ Proceedings of the Medical Board, 23 July 1804 , entered in: TNSA, Madurai DR vol. 1190, fols 164-6. According to these figures vaccination began in September 1802.

${ }^{25}$ For Bombay, see J Banthia and T Dyson, 'Smallpox in nineteenth-century India', Popul. Dev. Rev., 1999, 25: 649-80, fig. 2 on p. 658. The scheme adopted in Bengal was based on fixed vaccination stations and turned out to be very inefficient. The system initially adopted in Madras was based on itinerant vaccinators and seems to have resembled the much more successful system inaugurated in the Bombay Presidency in 1827 and later adopted in Madras in 1865. Arnold, op. cit., note 5 above, pp. 136, 144-5. The conclusions drawn from vaccination statistics must be taken to express broad tendencies only. For a warning against the reliability of vaccination statistics throughout the nineteenth century, see Bhattacharya, et al., op. cit., note 21 above. 


\section{Variolation, Vaccination and Popular Resistance in South India}

practice of vaccination. In the southern districts, on the other hand, variolation had never made an impact and there was no rival practice to vaccination. ${ }^{26}$ In any case, there were several reports indicating difficulties in the northern districts in 1803 and 1804. Strains of the vaccine disease were lost-presumably because it had to be carried over long distances in the sparsely populated tracts-and in 1804 there was an outbreak of smallpox in Rajahmundry. ${ }^{27}$ From the earlier so successful Masulipatam District "tardiness and reluctance" among the Indian population was suddenly reported. ${ }^{28}$ In March 1804 the surgeon in Madepollam and Ingeram announced that the number of vaccinations was declining, and in October the Medical Board realized that there had been no vaccination activities in Vizagapatam District since 1802. ${ }^{29}$ The situation in the northern districts is summed up in a desperate letter from the superintending surgeon to one of his subordinates in Masulipatam, urging him to forward new subjects for vaccination: "I see no prospect of success in the cases lately vaccinated; - therefore, push off; I beg you with new Subjects, as soon as possible hither, without further Advice of me-" [emphasis in original]. ${ }^{30}$

The campaign came under pressure in 1804. The meagre results in the northern districts provoked explicit criticism from government. Although the government acknowledged the initial efforts to promote vaccination in the northern districts, it also expressed concern "at the apparent remissness which has since prevailed". If the reason, as alleged by the Medical Board, was a decline in vaccine potency, the government felt that "it must be a Cause not less of regret than surprize [sic] to his Lordship, in Council, that the facts should not have been Known at an earlier period". ${ }^{31}$ James Anderson, physician general and first member of the Medical Board, also recognized that the campaign had not lived up to expectations. Anderson voiced his optimism in September 1804 in a communication to the Government Gazette: "Progress towards the extermination of Small-Pox is become so promising, that, I have little doubt, the Cow-Pock Lancet will soon be as familiar to the Hindoos, as the Plough or the Shuttle". Four months earlier, however, he had written to Dr H Scot in Bombay, complaining that the number of vaccinations in the Madras Presidency was far too small to nourish any hopes of exterminating the disease. ${ }^{32}$

If the campaign against smallpox came under pressure in 1804, it turned into a severe crisis by the end of the year. In November, the garrison surgeon of Fort St George, Alexander Mackenzie, wrote a letter to the Governor, Lord William Bentinck, pointing out the shortcomings of the present system and submitting proposals for revisions. ${ }^{33}$ This letter ignited a heated debate about the best way to promote vaccination, in which the character of the indigenous vaccinators and the way the colonial administration had engaged with them immediately became a central issue. Mackenzie criticized the system of rewarding each

\footnotetext{
${ }^{26}$ A similar pattern has been found in Britain, where well-established variolation seems to have inhibited the dissemination of vaccination. Razzell, op. cit., note 2 above, pp. 77, 99-100.

${ }^{27}$ TNSA, SGR vol. 14, fols 84-9. Proceedings of the Medical Board, 21 May 1804, entered in: TNSA, Madurai DR vol. 1190, fol. 150.

${ }^{28}$ TNSA, SGR vol. 14, fols 106-7.

${ }^{29}$ TNSA, Madurai DR vol. 1190, fols 163, 268.

${ }^{30}$ TNSA, SGR vol. 14, fol. 103 . This passage also indicates how unreliable early vaccination was.
}

\footnotetext{
${ }^{31}$ Government resolution on the proceedings of the Medical Board, 21 May 1804, entered in: TNSA, Madurai DR vol. 1190, fol. 150.

${ }^{32}$ James Anderson, Correspondence for the extermination of small-pox. Madras, collected and reprinted by Francis Lawrance, 1804, pp. $6,18$.

${ }^{33}$ BL-OIOC P/255/43 Madras Military Proceedings (hereafter MMP), 21 Dec. 1804, fols 6404-15.
} 


\section{Niels Brimnes}

vaccinator with a premium in proportion to the number of vaccinations performed and believed that if they were paid a fixed monthly salary, many of the campaign's problems would be solved. The Medical Board, on the other hand, fiercely defended the system that had developed under its guidance and supervision. The debate, which I shall analyse in more detail below, ended with an almost complete defeat for the Medical Board. In June 1805 the system of vaccination was changed according to Mackenzie's suggestions: vaccination against smallpox was redefined as a "civil Regulation rather than a Medical Practice", relocated to the Judicial Department, and Mackenzie was appointed as the new superintendent of vaccination. ${ }^{34}$

Under the superintendence of Mackenzie the campaign expanded. His reports emphasized how the costs had been reduced, while the number of vaccinations had risen. In the first year under the new system (September 1805 to August 1806) 178,074 were returned as vaccinated, this rose to 243,175 in the second year. The area around Madras was now the most successful in terms of the number of vaccinations, but the northern districts had clearly caught up with the rest of the Presidency. The number of indigenous vaccinators had also gone up from the 66 listed in 1805 to 141 in October 1806 and 156 in October 1807. In 1812, however, the number was only slightly higher at 177 , and more than a decade later the problems which had been identified since the introduction of vaccination remained: erroneous practice and lack of efficient control of the vaccinators. ${ }^{35}$ In 1821 the superintendent of vaccination, William Scot, suggested a number of changes to the system. Scot advised that the responsibility for overseeing the practice of vaccination be moved once again, this time to the collectors and the revenue department. ${ }^{36}$

More than three decades had passed since Nicol Mein reported the successful inoculation of European troops in Trichinopoly, but with a population in the Madras Presidency of approximately 15 million, the colonial authorities were still far from making any significant impact on the occurrence of smallpox in south India. ${ }^{37}$ The early efforts to combat the disease were, however, significant in other ways. They were an early attempt to reach out to large parts of indigenous society and to bestow upon it what the colonial authorities believed to be a highly benevolent practice. It is worth analysing in greater detail the reactions to these efforts as well as how the campaign was conceptualized by the colonial authorities in the light of these reactions.

\section{Techniques of Prevention}

Before dealing in more detail with indigenous reactions to the campaign against smallpox, I shall describe the techniques involved. In order better to understand the pattern of indigenous resistance, it is particularly useful to consider to what extent and in what way the

\footnotetext{
${ }^{34}$ BL-OIOC F/4/201, Board's Collections no. 4544, fols 4, 31-2.

${ }^{35}$ BL-OIOC P/255/53 MMP, 19 June 1805 , fols 4063-5. F/4/201, Board's Collections no. 4544, fols 9-10. F/4/268, Board's Collections no. 5891, fols 31, 38, 42, 48-9, 54-5, 60; F/4/382, Board's Collections no. 9625 , fol. 126.

${ }^{36}$ BL-OIOC P/294/1, Madras Board of Revenue Proceedings, 12 Nov. 1821, fol. 10051.
} 


\section{Variolation, Vaccination and Popular Resistance in South India}

techniques of variolation and vaccination would have appeared as different from each other to the south Indian population. Unfortunately, descriptions of the techniques actually employed in south India in the early decades of the nineteenth century are virtually absent. It is possible to obtain some information from accounts relating to other areas and later periods, but it is important to emphasize that techniques varied over time and between different localities-perhaps even between individual inoculators. ${ }^{38}$ Greatly simplifying the issue, we can say that three "models" of smallpox prevention interacted in early colonial south India: Indian variolation, British variolation and early vaccination.

One of the most influential accounts of variolation as practised in India was published by JZ Holwell in 1767 and described the practice in mid-eighteenth-century Bengal. According to Holwell, variolation was conducted by a specific group of itinerant Brahman inoculators. Up to a month before variolation the "patients" were prepared through a diet that excluded fish, milk and ghee (clarified butter). The Brahmans preferred to variolate males in the arm and females in the shoulder, and the operation itself was described as follows:

The operator takes a piece of cloth in his hand ... and with it gives a dry friction on the part intended for inoculation, for the space of eight or ten minutes; then with a small instrument he wounds by many slight touches, about the compass of a silver groat, just making the smallest appearance of blood. Then opening a linen double rag, (which he always keeps in a cloth round his waist,) he takes from thence a small pledget of cotton charged with the variolous matter, which he moistens with two or three drops of the Ganges water, and applies it to the wound, fixing it on a slight bandage, and ordering it to remain on for six hours without being moved, then the bandage to be taken off, and the pledget to remain until it falls off itself. ${ }^{39}$

The most significant measures taken after the operation were to pour cold water over the head of the inoculated person until the fever came on and to ensure that an offering was made to Sitala, the goddess of smallpox in Bengal. ${ }^{40}$ In 1805 John Shoolbred, SuperintendentGeneral of Vaccine Inoculation in Bengal, described Holwell's account as agreeing "in general pretty nearly, with the state of small-pox inoculation by the Brahmins at the present period". ${ }^{41}$ Whitelaw Ainslie-an acknowledged doctor of the Madras Medical Service-briefly described variolation, as he had seen it in the Ganjam area in the late eighteenth century. Generally, Ainslie's account was in agreement with Holwell's, although he put slightly more emphasis on the religious authority of the inoculators, mentioned that some "opening medicine" was given before the operation and described the wound through which the variolous matter was introduced, as an "incision". 42

As mentioned above, indigenous variolation was rare in the Madras Presidency and we must assume that variolations performed under colonial auspices until the advent of vaccination resembled the practice of variolation as it had evolved in Britain, at least as much as it resembled that of India. Indian and British procedures of variolation might not, however,

\footnotetext{
${ }^{38}$ Arnold 1993, op. cit., note 5 above, p. 120; Bhattacharya, et al., op. cit., note 21 above.

${ }^{39}$ Quoted from John Shoolbred, Report on the progress of vaccine inoculation in Bengal, from the period of its introduction in November 1802 to the end of the year 1803, Calcutta, Honorable Company's Press, 1804, Reprint: London, Blacks and Parry, 1805, p. 73.
}

\footnotetext{
${ }^{40}$ Ibid., 74. On Sitala, see Susan S Wadley, 'Sitala, the cool one', Asian Folklore Studies, 1980, 39: 33-62; Ralph W Nicholas, 'The Goddess Sitala and epidemic smallpox in Bengal', J. Asian Stud., 1981, 41: 21-44. The south Indian equivalent of Sitala was the less prominent goddess Mariamman.

${ }^{41}$ Shoolbred, op. cit., note 39 above, p. 75.

${ }^{42}$ Ainslie, op. cit., note 8 above, pp. 63-4.
} 


\section{Niels Brimnes}

have appeared very different. William Ward declared in an account of Indian practices that the "method of introducing the virus is much the same as in Europe". ${ }^{43}$ British commentators often portrayed Indian practices of variolation as accompanied by unnecessary ritual, as did the Collector of Vizagapatam when in 1801 he claimed that it was performed "with many Superstitions \& unnecessary Ceremonies". ${ }^{44}$ But the British method was itself quite elaborate, and in 1815 James Moore declared that the simple eastern practice became "complicated daily" by British physicians during the eighteenth century. Recently both Peter Razzell and Maisie May have reiterated this view. Razzell refers in a somewhat idealizing way to "the original simple method of inoculation practised in Turkey, India and elsewhere", while May describes variolation in Britain as "ritualized inoculation". Both authors do, however, point out that the practice in Britain became simpler and more standardized in the second half of the century. ${ }^{45}$ British practitioners also "prepared" their patients with dietary prescriptions, devised according to the humoral theory of disease. According to one eighteenth-century account, "the Purpose and Scope of Preparation is to Remove or lessen the inflammable State of the Blood, and the Extreme Tension of the Solids; but not to depress the Vis Vitae ..." [emphasis in original]. ${ }^{46}$ Baron Dimsdale, whose "method" was explicitly referred to by Nicol Mein, partly attributed his success to the application of a strict, "cooling" diet. ${ }^{47}$ As in India, the variolous matter was normally inserted through an "incision" in the arm, and after the operation emetics and laxativesperhaps even bleeding-might be prescribed. ${ }^{48}$

There was, however, one striking difference between Indian and British variolation: while the Indian inoculator used dried matter-according to Holwell it was from the previous year-the British preferred to use fresh matter taken directly from a ripe pustule. ${ }^{49}$ Moreover, from contemporary British accounts it seems clear that British practitioners had little confidence in techniques of storing variolous matter over longer

\footnotetext{
${ }^{43}$ William Ward, A view of the history, literature, and mythology of the Hindoos, 2nd ed., 2 vols, Serampore, Mission Press, 1818, vol. 1, p. 477. Ward was referred to by Whitelaw Ainslie as well as by Daniel Robert Thompson, Superintendent of Vaccination in Madras in the mid-nineteenth century. Ainslie, op. cit., note 8 above, p. 63; Daniel Robert Thompson, A treatise on vaccination, Madras, Gantz Brothers, 1864, p. 3.

${ }^{44}$ BL-OIOC F/4/96, Board's Collections no. 1953, fol. 83 .

${ }^{45}$ James Moore, The history of the small pox, London, printed for Longman, Hurst, Rees, Orme, and Brown, 1815, pp. 253-4, 265. Razzell, op. cit., note 2 above, p. 20. Maisie May, 'Inoculating the urban poor in the late eighteenth century', Br.J. Hist. Sci., 1997, 30: 291-305, pp. 304, 294-6. The simplification was in large part due to the gradual adoption of the method developed by Robert and Daniel Sutton in the 1760s.

${ }^{46}$ Kirkpatrick, op. cit., note 2 above, p. 301. Cf. Razzell, op. cit., note 2 above, pp. 12-13.

${ }^{47}$ Baron Dimsdale, The present method of inoculating for the small-pox, 6th ed., London, W Owen, 1772, pp. 4, 78. It did occur to Dimsdale
}

that the dietary preparation might be superflous, but he dared not "by way of experiment, dispense with the use of measures that had been hitherto so successful". Ibid., p. 82. See Kirkpatrick, op. cit., note 2, pp. 283-6, for similar considerations. Elaborate preparation of the patient lost importance in Britain in last decades of the eighteenth century. Razzell, op. cit., note 2 above, pp. 14-16. On the conceptual level, the attempt to keep the patient cold found a parallel in the Indian belief in Sitala. According to Susan Wadley, Sitala "abhors heat and all things hot and she eats primarily stale (cold) food and other cool things". Wadley, op. cit., note 40 above, p. 54.

${ }^{48}$ Dimsdale, op. cit., note 47 above, pp. 23 , 30, 33, 79-80. Kirkpatrick, op. cit., note 2 above, pp. 193, 329, 344

${ }^{49}$ Shoolbred, op. cit., note 39 above, p. 73. It is, however, not possible to establish an absolute distinction between an "Indian" and a "British" method. For references to Indians using fresh matter, see Nicholas, op. cit., note 40 above, p. 28. A rare example of storing variolous matter for years in Britain was reported from the Shetland Islands in 1792. Razzell, op. cit., note 2 above, p. 23. 


\section{Variolation, Vaccination and Popular Resistance in South India}

periods. ${ }^{50}$ In other words, by contrast to the Indian practice, "British" variolation was predominantly an arm-to-arm technique.

The advent of vaccination changed the operation to a limited extent only. Infected matter was still inserted through an incision in the arm, but the perishable nature of the vaccine made it even more advisable to use the arm-to-arm technique. In south India vaccine was, however, sometimes sent from place to place on infected thread, and in October 1804 the Medical Board declared that vaccination was much more reliable if "the genuine infection is Communicated immediately from patient to patient instead of conveying the virus from a distance [on] any immediate substance, by which it may be vitiated or decomposed". 51 After the operation, vaccination produced a less visible reaction, sometimes leading to doubts whether it had been successful. ${ }^{52} \mathrm{~A}$ final visible difference between variolation and vaccination seems to have been that the ritual aspects of the operation were played down in vaccination: not only was the invocation of deities absent, but elaborate preparation and subsequent therapeutic interventions were also lacking. In this way vaccination appeared to be what Harish Naraindas has called the "prototype prophylactic": no preparation, a simple operation and no significant care afterwards. ${ }^{53}$

To sum up, two important technical transformations appear to have taken place in the process by which Indian techniques of smallpox prevention were replaced by methods developed in Europe. First, the arm-to-arm technique gained ground. The effects of this are uncertain. David Arnold has suggested that the visible and immediate transfer of bodily fluids from one individual to another may have offended Indian conceptions of bodily purity. ${ }^{54}$ Other writers have drawn attention to secular reasons for opposing vaccination. Sanjoy Bhattacharya has argued that vaccination was unreliable, quite painful and often led to complications, while Harish Naraindas has emphasized the inconvenience it must have caused to children chosen as vaccinifers (and to their families) to be driven from village to village. ${ }^{55}$ Second, although the basic operation remained virtually the same, the ritual and therapeutic interventions surrounding it became less important. In this Arnold has seen an opposition between the ritualized practice of indigenous variolation and the "raw secularity" of vaccination, while Naraindas prefers to conceptualize this difference as the therapeutics of variolation against the prophylactics of vaccination. ${ }^{56}$ Both authors

\footnotetext{
${ }^{50}$ While dried matter was stored from season to season in Bengal, Kirkpatrick only claimed that he had "certain Demonstration" that variolous matter could remain active for several weeks. Kirkpatrick op. cit., note 2 above, p. 211. Dimsdale's account conveys a similar impression: "If neither an inoculated patient is at hand, nor anyone in the neighbourhood has a distinct kind of the natural disease, a thread may be used as in the common manner, provided that the thread be very recently infected; but I think it ought to be used as soon as possible after being charged with infecting matter." Dimsdale, op. cit., note 47 above, p. 29.

${ }^{51}$ Proceedings of the Medical Board, 29 October 1804, entered with enclosures in: TNSA, Madurai DR, vol. 1190, fols 271-2. For references to the use of infected thread, see, for example, Shoolbred, op. cit. note 39, p. 45. TNSA, SGR vol. 14, fols 84, 173.
}

${ }^{52}$ Razzell, op. cit., note 2 above, p. ix.

${ }^{53}$ Naraindas, op. cit., note 21 above, p. 67.

${ }^{54}$ Arnold, op. cit., note 5 above, p. 141.

${ }^{55} \mathrm{~S}$ Bhattacharya, 'Re-devising Jennerian vaccines? European technologies, Indian innovation and the control of smallpox in South Asia, 1850-1950', in B Pati and M Harrison (eds), Health, medicine and empire: perspectives on colonial India, New Delhi, Orient Longman 2001, pp. 217-69, on pp. 255-6, 261; Bhattacharya, et al., op. cit, note 21 above; Naraindas, op. cit., note 21 above, p. 86 .

${ }^{56}$ Arnold, op. cit., note 5 above, pp. 143-4; Naraindas, op. cit., note 21 above, p. 70. For an even more pronounced expression of the difference between Western and Indian conceptualizations of disease, see Frédérique Apfell-Marglin,

'Smallpox in two systems of knowledge', WIDER Working Papers, 1987, No. 17. 


\section{Niels Brimnes}

point, however, to the fact that an important difference between variolation and vaccination lay in the broader cultural context in which the practice was embedded.

We must, however, be very careful not to apply these "models" uncritically in the following analysis of smallpox prevention in south India. Not only because of the rarity of indigenous variolation, but also because the actual practice was arguably too heterogeneous and syncretic to conform to these models. Did the inoculators employed by the Zamindar of Chintapilly follow the practice of the Brahmans in Bengal or Ganjam, or that of Dr Binny when he variolated the Zamindar? Can we assume that the indigenous inoculators "prepared" their patients during the campaign up to 1803? Can we, on the other hand, assume that the vaccinators employed by the colonial authorities a few years later conformed to the "raw secularity" of vaccination and did not add therapeutic interventions? Rather, it seems likely that the different techniques mingled to create a range of specific and syncretic practices that did not fit the abstract "models" discussed in this section. This point is illustrated in a mid-nineteenth-century account from Madras, in which it is revealed that the practice of pouring cold water over the head of the patient-a practice connected with the model of "Indian variolation"-persisted in a "greatly modified" form along with vaccination:

This practice seems to have been handed down to the present generation and is still scrupulously followed, but greatly modified: for, instead of cold water being poured on the head and shoulders, as was formerly the case, the child gets a general warm bath on the third or fifth day, as one or the other may be deemed the more propitious. ${ }^{57}$

According to the observer - the Superintendent of Vaccination in the Madras Presidencythis and other syncretic practices limited the effectiveness of the vaccine, and ought to be prevented by instructions given after the operation. If the Indians were given such instruction before the operation, the superintendent argued, "they will very often object to the performance of it". 58

\section{Patterns of Resistance}

In 1804 Surgeon J Dalton was conducting vaccinations in Trivatore in the Chingleput District not far from Madras and found himself surrounded by thousands of angry Indians. According to Dalton, they declared that "rather then [sic] allow me or any one to be vaccinated in, or near the Village, they would suffer death". He explained their action as due to the widespread belief that the practice of taking down personal details of every vaccinated person was a prelude to either a capitation tax or transportation. Eventually, Dalton had to escape from the scene and leave the duty of vaccination to Sawmy Naik, one of the most successful indigenous vaccinators. ${ }^{59}$ The violent obstruction experienced by Dalton was one of the rare dramatic manifestations within south Indian society of outright resistance to the campaign against smallpox. As immunization was never forced upon the

\footnotetext{
${ }^{57}$ Thompson, op. cit., note 43 above, p. 20.

${ }^{58}$ Ibid, p. 21.

${ }^{59}$ BL-OIOC P/255/53 MMP, 19 June

1805, fols 4096-7. See also Sawmy Naik's
} account printed in Indian Medical Gazette, Oct. 1902: 413-14. 


\section{Variolation, Vaccination and Popular Resistance in South India}

Indian population, hesitant or sceptical Indians could simply ignore the offer. In this sense non-acceptance might be a more adequate description of indigenous attitudes than straightforward "resistance". ${ }^{60}$ Although it is impossible to establish the extent of the resistance, there can be no doubt that Indians in the districts subordinate to Madras were as reluctant to accept variolation as to submit to vaccination. This undermines the notion of a simple opposition between variolation as widely acceptable to the indigenous population and vaccination as alien and oppressive. It is, moreover, important not to treat indigenous resistance as a general phenomenon, but to emphasize its varied nature and specific causes. We need to look for a pattern.

As discussed above, the relative decline in the number of immunizations in the previously so successful districts of Guntur and Masulipatam and the significant rise in the southern districts, might be connected to the shift of the campaign from promoting variolation to promoting vaccination. Apart from this, however, it has not been possible to identify differences between the opposition to variolation and that to vaccination. Nor are there any clear indications that indigenous resistance can be understood in terms of social stratification or ritual hierarchies. Perhaps the only large community that was particularly hostile towards vaccination was that of the Mapilla Muslims in Malabar, and this hostility does not seem to have been the reaction of Muslims in general. ${ }^{61}$ For other communities the evidence is more contradictory. In 1802 it was reported from the Black Town of Madras that resistance came mainly from "the higher orders of the Natives". It was difficult to get access to the houses of these groups and the Medical Board recommended that more Brahman inoculators be employed to overcome this problem. From Travancore it was also reported that it was chiefly Christians and low-caste Hindus that accepted vaccination; ${ }^{62}$ there were, however, also reports of great readiness on the part of the Brahmans. The collector of Coimbatore explicitly rejected the notion, expressed by James Anderson, that south Indian Brahmans were "prejudiced against inoculation" and from the northernmost part of the Presidency the surgeon of Madepollam and Ingeram referred to the readiness among Brahmans to submit their families to inoculation. ${ }^{63}$

The admittedly unreliable vaccination statistics further indicate that resistance cannot be attributed to certain social groups. The 4,588 persons variolated in the 1801/2 season in Masulipatam District can be broken down to occupational groups that show that variolation was accepted among a variety of people from Brahmans to low ranking barbers and dancing girls (see Table 2). From the figures it seems that variolation was more common among the higher-ranking groups, but we need to know more about the composition of the entire

\footnotetext{
${ }^{60}$ Neither troops nor prisoners seem to have been subject to compulsory immunization. For the voluntary inoculation of troops, see, for example, TNSA, SGR vol. 12, fol. 261. In March 1802 the sub-collector of Bhovany wrote to the commanding officer at Erode that inoculation among prisoners ought to be encouraged but should rest "upon the consent of the Natives themselves". He further wished it to be understood that he took upon himself "the responsibility of the bodily safety of the Prisoners" TNSA, Coimbatore DR vol. 593, fols 70-1. I shall
}

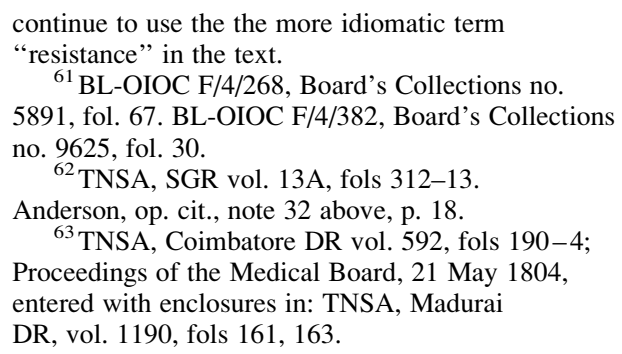

continue to use the the more idiomatic term "resistance" in the text.

${ }^{61}$ BL-OIOC F/4/268, Board's Collections no. 5891, fol. 67. BL-OIOC F/4/382, Board's Collections o. 9625 , fol. 30

${ }^{62}$ TNSA, SGR vol. 13A, fols 312-13

Anderson, op. cit., note 32 above, p. 18.

Proceeding

DR, vol. 1190, fols 161, 163 . 


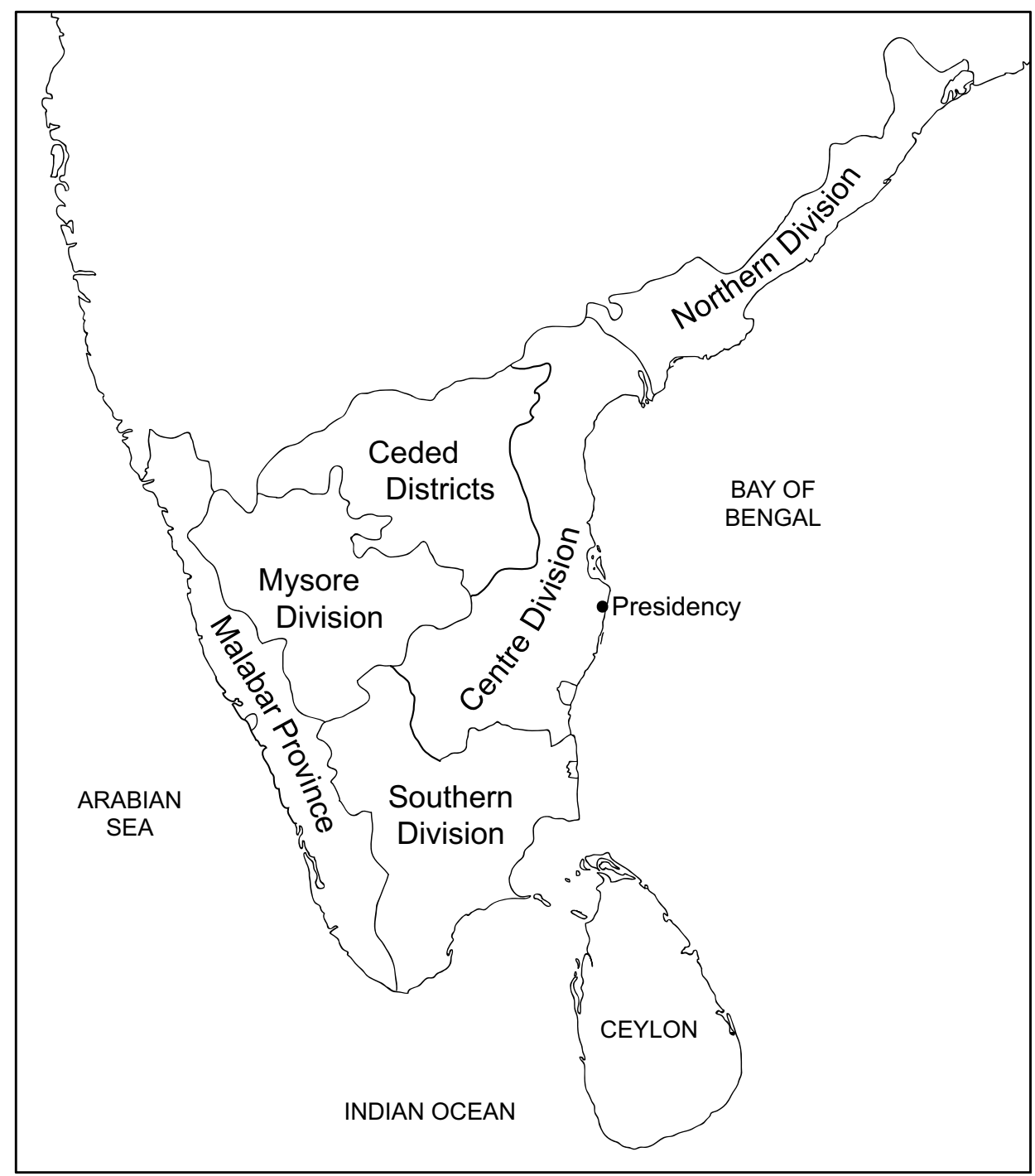

Figure 2: Divisions of the Madras Army and Medical Service in the early nineteenth century. 


\section{Variolation, Vaccination and Popular Resistance in South India}

Table 2

Persons inoculated in Masulipatam District in 1802 (representing 10 villages in the district)

\begin{tabular}{lrrr}
\hline Group & Male & Female & Total \\
\hline Brahmans & 342 & 440 & 782 \\
Banians (Merchants) & 19 & 16 & 35 \\
Weavers & 24 & 21 & 45 \\
Goldsmiths & 25 & 28 & 53 \\
Ironsmiths & 91 & 99 & 190 \\
Cow keepers & 27 & 24 & 51 \\
Washermen & 19 & 22 & 41 \\
Paddy Drawers & 37 & 85 & 122 \\
Tailors & 2 & 8 & 10 \\
Fishermen & 8 & 8 & 16 \\
Carpenters & 11 & 0 & 11 \\
Dancing Girls & 5 & 10 & 15 \\
Barbers & 5 & 9 & 14 \\
Basket People & 4 & 6 & 10 \\
"Gentoo Men" $\quad 1376$ & 1098 & 2474 \\
$\quad$ (unspecified Hindus of Telugu origin) & & & \\
Muslims & 82 & 71 & 153 \\
Unidentified & 230 & 320 & 550 \\
Total & 2307 & 2265 & 4572 \\
\hline
\end{tabular}

Not included are 10 persons inoculated in Masulipatam itself and an apparent error of 6 individuals.

Source: TNSA, SGR vol. 13A, fols 456-70.

population in specific villages. The figures also show that women were only slightly less likely to be inoculated than men. Less precise is the breakdown of the more than 145,000 persons vaccinated in the entire Presidency between September 1802 and April 1804, but it does confirm that all major groups in south Indian society were among the vaccinated (see Table 3). Here, the number of vaccinated women was about 10 per cent lower than the number of vaccinated men. We can not, of course, assume that each social group was targeted with equal intensity during the campaign. If the number vaccinated between September 1802 and April 1804 is compared with the number of certified vaccinators within the same broadly defined group, it emerges that the proportion of Brahman vaccinators was much higher than the proportion of vaccinated Brahmans (see Table 3). Paraiyans and Kannada-speaking Hindus, on the other hand, were seriously under-represented among the vaccinators. ${ }^{64}$ If certain groups appeared less likely to accept immunization this may not have indicated resistance but a lack of opportunities. ${ }^{65}$

\footnotetext{
${ }^{64}$ Paraiyans (or Pariah) refers to a numerous low ranking community of Tamils. Since there are no references to the non-Tamil equivalents of Paraiyans, the term probably refers to all low-ranking communities (approximately what would later be
}

termed "untouchables" and even later "harijans" and "dalits").

${ }^{65}$ This is of course based on the assumption that immunizers from a specific group tended to practise within that group. 


\section{Niels Brimnes}

Table 3

Persons immunized (1802-4) and number of vaccinators (1805)

\begin{tabular}{lccc}
\hline Group & $\begin{array}{c}\text { Persons } \\
\text { immunized } \\
1802-4\end{array}$ & $\begin{array}{c}\text { Number of } \\
\text { vaccinators } \\
1805\end{array}$ & $\begin{array}{c}\text { Immunized per } \\
\text { vaccinator within } \\
\text { each group }\end{array}$ \\
\hline Brahmans & 4141 & 10 & 414 \\
"Gentoos" (Telugu Hindus) & 40036 & 23 & 1741 \\
Malabars (Tamil Hindus) & 41806 & 26 & 1608 \\
Paraiyans* & 35975 & 1 & 35975 \\
Muslims & 10926 & 3 & 3642 \\
Kannadas & 10367 & 0 & - \\
Others & 2603 & 3 & - \\
Total & 145845 & 66 & - \\
\hline
\end{tabular}

*Paraiyan might refer either to a specific community of low ranking Tamils or more broadly to low ranking ("untouchable") communities throughout south India.

The table from which the figures of persons immunized has been computed displays minor inaccuracies. These are, however, all below 100 persons and thus not of any significance for the overall picture.

Sources: Proceedings of the Medical Board, 23 July 1804, entered with enclosures in: TNSA, Madurai DR vol. 1190 fol. 166; BL-OIOC, P/255/53 MMP, 19 June 1805, fols 4063-65.

Indigenous resistance seems to have been primarily determined by local conditions rather than social stratification or status hierarchies. As noted above, one of the most significant features of the early campaign was its remarkable concentration in Guntur and Masulipatam districts and this was presumably a result of the initiative shown by the Zamindar of Chintapilly. Similarly, from Madurai District, where local magnates such as the Rani of Ramnad and the Zamindar of Shivagangai supported vaccination, it was reported in 1803 and 1804 that "the people in general seem perfectly reconciled to the operation" ${ }^{66}$ Not surprisingly, attempts to get leading figures in the indigenous society to endorse immunization and submit their own families to the operation were the preferred strategies in the campaign. Thus, in 1801, the collector in Rajahmundry believed he could overcome widespread resistance if he succeeded in inoculating "the better sort and more enlightened of the inhabitants". In 1804 James Anderson noted with satisfaction that not only were the Zamindar of Chintapilly and the Rajah of Tanjore favourably disposed towards vaccination, but even the Diwan of Travancore had submitted himself to the operation. ${ }^{67}$

Local differences in attitude towards inoculation could, of course, not always be explained with reference to the stance taken by local leaders. Assistant Surgeon A Smith reported from Severndroog in Salem District that he found the inhabitants too hesitant and had crossed the border to neighbouring Coimbatore District, where the population was

\footnotetext{
${ }^{66}$ TNSA, SGR vol. 14 , fol. 60 . TNSA, Madurai DR vol. 1147, fols 54-5.

${ }^{67}$ BL-OIOC F/4/96, Board's Collections no. 1953 , fol. 98 . Anderson, op. cit., note 32
}

above, p. 18. The Zamindar of Chintapilly had been variolated in the 1790 s and subsequent vaccination would not have had any impact on his immunity. 


\section{Variolation, Vaccination and Popular Resistance in South India}

much more inclined to accept vaccination. Smith explained this difference as the result of British officers in Coimbatore impressing "on the minds of the Inhabitants" the great benefits deriving from vaccination. ${ }^{68}$ While the efforts of colonial officials were probably of less importance than Smith assumed, a number of other local conditions may have influenced the degree to which the inhabitants accepted vaccination. Among the most obvious are the incidence of smallpox outbreaks in the area and the relationship between indigenous immunizers on the one hand and the local population on the other.

Indians were reluctant to accept immunization for a number of specific reasons. First, it is quite natural that any group of people would hesitate to accept the implementation of unknown practices directly on the body and largely performed by outsiders to the local community. The use of arm-to-arm techniques may also have offended conceptions of bodily purity for certain groups, while others probably opposed the campaign because the operation was painful, inconvenient and often failed. There are also indications that the connection between vaccination and the cow caused anxiety among Indians. ${ }^{69}$ Finally, as Dalton's incident at Trivatore suggests, Indians were suspicious of the distant ruler's motives for such intrusive intervention in their daily life. ${ }^{70}$

Whatever the reasons behind the various forms of resistance, the colonial authorities had to make sense of them, and they generally had recourse to the standard colonial conceptualization of Indian society as static and traditional, immobilized by an age-old aversion to change and innovation. Moreover, having lived for so long under oppressive and despotic regimes, the Indians were not capable of understanding the benevolent motives of the British. Two documents from 1805 provide examples of how the colonial authorities perceived indigenous resistance. The first was written by the French missionary J A Dubois, who worked for many years as superintendent of vaccination in Mysore. In a letter to the superintending surgeon of the southern division of the army he listed the "objections" that he had encountered throughout his career:

- Their opposition to everything which was not transmitted to them by their forefathers.

-A want of confidence in the remedy which is not yet become general enough.

-A distrust about the generous views of government, these poor people, to these last times accostomed [sic] to live under a Government, who had recourse to every kind of craft and imposture to oppress them, imagine that so much trouble is taken, and the great expenses gone to by their rulers not to benefit but to injure them; and that their Children when grown up, shall be carried away, or that at least an heavy tax shall be levied as a compensation for the benefit bestowed on them by vaccination.

- A fear of irritating the Goddess of small pox Mariamma, and being exposed to her revenge.

\footnotetext{
${ }^{68}$ TNSA, SGR vol. 14, fols $174-5$.

${ }^{69}$ Thus the Indian terms chosen for cowpox seem to have generated unfortunate connotations among Indians. Wujastyk, op. cit., note 19 above, pp. 152-3. BL-OIOC F/4/153, Board's Collections no. 2613, fols 125-6. In Europe, too, uncertainty about the relation between humans and an animal disease caused some anxiety. Cartwright, op. cit., note 1 above, p. 89. Eberhard Wolff,

Einschneidende Massnahmen. Pockenschutzimpfung
}

\author{
und traditionale Gesellschaft im Württemberg des \\ frühen 19. Jahrhunderts, Stuttgart, Franz Steiner, \\ 1998, pp. 442-4. \\ ${ }^{70}$ That popular resistance should be seen \\ essentially as a political protest against the \\ disciplinarian activities of the state has been \\ suggested by Apffel-Marglin. This explanation seems, \\ however, far too one-sided. Apffel-Marglin, op. cit., \\ note 56 above, pp. 18, 22.
}




\section{Niels Brimnes}

- But the obstacle which is not the least of all, and which cannot be easily removed, proceeds from the apathy and want of forecasting in the Hindoos. - The former makes them insensible to every evil which is yet distant; and the latter makes them perfectly indifferent about the perils which are not near at hand. - [emphasis in original. $]^{71}$

The second document is a letter written in 1805 by Captain Blackburne from Tanjore District. In this area widespread resistance was reported from the outset of the campaign. In 1802 the collector referred to "the extreme prejudice and Dread felt in this province against the unnatural communication of the Small Pox". Despite having sent seven natives to Trichinopoly for instruction in the practice of variolation, the collector lamented: "All that I can offer for congratulation is that it is introduced. Not only the known prejudice and apprehension of the People but their numbers are obstacles, and these are Co-operated with by the Procrastinations and slowness of the native Practitioners". ${ }^{72}$ In his letter Blackburne also paid attention to the conduct of native agents, but began his account with an unusually explicit version of the frequently made reference to prejudice and superstition within Indian society:

... this aversion is to be attributed chiefly to religious prejudices and partly to the reluctance with which the Hindoos accept of every innovation and change. In no part of India perhaps are the religious prejudices so strong, nowhere are all the forms and Institutions accumulated by the growing Superstition of Ages so carefully preserved as in Tanjour. ${ }^{73}$

After this general censure of Indian society, Blackburne criticized the abrupt shift from variolation to vaccination. Having taken great pains to introduce variolation in Tanjore, its "sudden and total Relinquishment" severely weakened the Indians' "confidence in the reasoning and assurances of the Europeans and augmented their natural aversion to the proposed change". ${ }^{74}$ Moreover, the first vaccinations were conducted by a European surgeon travelling through the district, who could not monitor whether his operations had been successful. When some of the patients later died from smallpox, this naturally led to "disgust and indignation" among the Indians. The subsequent conduct of the native vaccinators only increased the rejection of vaccination. According to Blackburne, they were interested only in the reward given in proportion to the number of vaccinations: they faked the lists of vaccinated and did not bother to check whether the vaccinations were actually successful. ${ }^{75}$ This criticism of the native vaccinator was identical to the objections raised by Alexander Mackenzie in 1804, treated in detail below. ${ }^{76}$ But Blackburne's account of the resistance in Tanjore was unusual because it mixed a general condemnation of indigenous society with specific criticism, not only of native agents, but also of strategies employed by the authorities in Madras, which were bound to appear inconsistent to the indigenous population.

Other reports of indigenous resistance were less elaborate. From Trichinopoly the collector reported in 1802 that the Indians saw variolation as "an unnatural and dangerous

\footnotetext{
${ }^{71}$ BL-OIOC P/255/53 MMP, 19 June 1805 , fols 4084-5.

${ }^{72}$ TNSA, Tanjore DR vol. 3207, fols 51-5.

${ }^{73}$ BL-OIOC F/4/201, Board's Collections no. 4544 , fols $39-40$.
}

\footnotetext{
${ }^{74}$ Ibid., fol. 40 .

${ }^{75}$ Ibid., fols $41-4$.

${ }^{76}$ Blackburne's letter was clearly utilized in the debate between Mackenzie and the Medical Board.
} 


\section{Variolation, Vaccination and Popular Resistance in South India}

Provocation" of a disease from which Providence might otherwise spare them. This probably reflected the view of many Indians that smallpox was a divine possession rather than a preventable disease. More peculiar was the belief, referred to by Surgeon Prichard from Tripassore, that if humans did not get smallpox, the cattle would get it instead. ${ }^{77}$

In the majority of letters and reports about the difficulties facing the campaign, however, the diverse reasons Indians had for opposing preventive measures against smallpox were routinely reduced to a standard phrase in the colonial vocabulary: indigenous prejudice and superstition. Immediately after Lord Clive decided to promote variolation, he wrote to London "that many Thousand Lives would be saved Annually, if the prejudices of the Natives did not so strongly oppose the introduction of the practice of Inoculation". In 1801 the Board of Revenue referred to the efforts of the Zamindar of Chintapilly as "an instance of superiority over the prejudices and superstition of the Hindoos in general", and from Rajahmundry the collector reported that not a single case of variolation had taken place "as the prejudice is so great at present against the practice of inoculation that no persuasions will induce them to submit to it". ${ }^{78}$

Prejudice and superstition were terms also commonly used as simplistic explanations of popular reactions towards campaigns against smallpox in Europe. In a study of the region around Lyons in France, Olivier Faure found that the medical discourse about popular attitudes was an image created to buttress the sense of superiority within the medical profession. ${ }^{79}$ Matthias Steinmann has argued that in the Swiss canton of Lucerne resistance stemming from specific experience with vaccination was conceptualized simply as superstition and prejudice. ${ }^{80}$ Similarly, in his recent impressive study of vaccination in the German state of Württemberg, Eberhard Wolff argues that notions of "indifference" and "prejudice" were employed by the state authorities more as a general condemnation of popular lifestyle than as a description of the actual reasons for resistance against vaccination. ${ }^{81}$ In a British context, eighteenth-century variolation was also accompanied by a rhetoric about popular indifference and prejudice, and these notions could still be found a hundred years later when vaccination was well established. ${ }^{82}$

Despite these similarities in official and medical discourse on popular reactions in Europe and India, it can be argued that colonialism added a deeper dimension to references to prejudice and superstition in medical matters. According to one recent analysis, the British around 1800 came to a fundamental understanding of India "as a land lost in the past, whose people were shaped by the heat of their climate, the distinctive character of their religion, and the immemorial antiquity of their social institutions". ${ }^{83}$ It is obvious that the rhetoric

${ }^{77}$ TNSA, Trichinopoly DR vol. 3661, fol. 159. TNSA, SGR vol. 14, fols 252-3. On smallpox as a divine possession, see Arnold, op. cit., note 5 above, p. 123.

${ }^{78}$ BL-OIOC F/4/96, Board's Collection no. 1953, fols 2, 15-16, 97.

${ }^{79}$ Olivier Faure, 'La vaccination dans la région Lyonnaise au début du XIXe siècle: résistances ou revendications populaires', Cahiers d'histoire, 1984, 29: 191-209, pp. 194, 208.

${ }^{80}$ Mathias Steinmann, 'Impf-Alltag im 19. Jahrhundert. Das Verhältnis zwischen Ärtzen und
Bevölkerung vor dem Hintergrund der Pockenschutzimpfung im Kanton Luzern', Gesnerus, 1995, 52: 66-82, pp. 72, 75, 79.

${ }^{81}$ Wolff, op. cit., note 69 above, pp. 413-36.

The German concepts analysed by Wolff included

"Gleichgültigkeit" and "Vorurteil".

${ }^{82}$ Razzell, op. cit., note 2 above, pp. 42-44, 51-53, 96. Anne Hardy, 'Smallpox in London: factors in the decline of the disease in the nineteenth century', Med. Hist., 1983, 27: 111-38, p. 115.

${ }^{83}$ Thomas Metcalf, Ideologies of the Raj, Cambridge University Press, 1994, p. 27. 


\section{Niels Brimnes}

accompanying the campaign against smallpox fitted neatly into this larger construction of Indian "otherness". On closer examination, however, the creation of "otherness" in India was a highly ambiguous process, and the remaining sections of this article are concerned with two instances in which the routine reference to Indian prejudice and superstition was not immediately applicable.

\section{From Variolation to Vaccination}

Because variolation was uncommon in the Madras Presidency, the campaign against smallpox before the arrival of the cowpox vaccine in 1802 was more than simply an encouragement of an indigenous practice: it was a deliberate if vastly inadequate attempt to introduce and diffuse the practice of variolation throughout south India. This made the situations before and after 1802 similar in many respects, but there was one important difference: variolation had indigenous roots whereas vaccination was completely foreign. While the change from promoting variolation to promoting vaccination did not influence the general rhetoric about indigenous prejudice and superstition, it brought about a significant change in the way in which the campaign was publicly announced. Despite the existence of resistance to variolation in India, the colonial authorities had to acknowledge that the practice was rooted in Indian society, that it was widely used further north in Bengal, and that the British had in fact learned it from Asians earlier in the eighteenth century. After vaccination was introduced, such credit to Indian medicine was no longer needed.

In a circular letter from Guntur, published in the very early stages of the campaign in November 1800, variolation was promoted exclusively with reference to its indigenous roots and indigenous agency:

The practice of Inoculation has been known from time immemorial in the Northern part of the Circars, and most of the [Woodiah] Zemindars Inoculate their Children; It is well known that it has been introduced, tho' lately in this Circar, by Rajah Vasareddy Vencatadry Naidoo, who first submitted to it himself and who now employs Native Doctors to inoculate such of the Inhabitants of this zemindary as are willing to submit to it. ${ }^{84}$

In the letter of recognition to Vencatadry Naidoo written less than a month later, however, Lord Clive focused on Indian prejudice but limited his criticism to the people of south India :

The only impediment to the successful practice of this part of the Art of Physic is derived from the prejudices of the Natives which is $[$ sic] founded in an Ignorance equally of the beneficial effects of the practice [and] of the principles on which the Objections are grounded, for it is notoriously known that the practice of Inoculation has been and still is familiar to whole Tribes of Hindoos in the Northern Provinces of Hindostan, while the prevailing ignorance in the Deckan annually dooms the greatest portion of the persons affected with this disorder to death. ${ }^{85}$

To Clive, the Zamindar's adoption of an indigenous technique was something that separated him from his fellow (south) Indians. By contrast to the population in general, the Zamindar possessed an unusual "understanding" and had applied his knowledge in

\footnotetext{
${ }^{84}$ BL-OIOC F/4/96, Board's Collection no. 1953, fols 45-6. The Zamindar referred to is the Zamindar of Chintapilly, and it is noteworthy that this circular
}

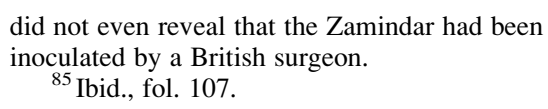




\section{Variolation, Vaccination and Popular Resistance in South India}

a "practical” way: "This liberal Consideration of a Question involved in much difficulty by the obstinate prejudices of the Hindoos, is a proof of the Vigor of your understanding and the practical use to which you apply your knowledge justly entitles you to the preeminence which you hold in the Ranks of society". 86

Despite this recognition of the indigenous roots of variolation, the colonial authorities from the outset sought to detach the practice from its Indian context. Variolation was presented as a technique that had been improved by the Europeans. When Nicol Mein reported his first variolations to Madras, it was noted that the patients had been prepared after "Baron Dimsdales method" and in 1800 the collector in Guntur wrote that variolation in Guntur had been introduced "in imitation of the European Method". ${ }^{87}$ In April 1801 the government envisaged that the inoculations performed by indigenous agents in the future would be conducted "at first according to the practice of the Northern Brahmins and gradually according to the improvements which may be suggested by the Medical Gentlemen of the district". ${ }^{88}$ The collector of Coimbatore was in no doubt that variolation was a technique controlled entirely by Europeans when he suggested to the Board of Revenue: "The first introduction of it under the Collectors inspection should of course be done by means of [a] European Surgeon; and Native Doctors-of whom some should be Brahmins - ought to be instructed by the European Surgeon and obliged to perform the operation in his presence". ${ }^{89}$ From Guntur, Assistant Surgeon James Peat explicitly criticized indigenous inoculators for not being careful enough. Referring directly to the inoculators employed by the Zamindar of Chintapilly, he declared: "I have seen patients labouring under the disease, and inoculated by the Rajah's People, who seem to think, that all that is required on their part, is to perform the operation, and give themselves no trouble to enquire into the result of their practice, but generally leave their Fate". ${ }^{90}$ It is, however, by no means certain that Peat was in fact criticizing a genuine "indigenous" practice. The indigenous practice of variolation seems to have been performed very carefully in many places and variolation had been introduced in Guntur by the British surgeon Dr Binny. ${ }^{91}$ The target of Peat's criticism, might, then, have been a skimped version of "British" variolation. Obviously, the detachment of variolation from its Indian roots was facilitated because the indigenous practice was so rare in the Madras Presidency. The fact—noticed by the Medical Board in April 1801 - that Europeans had embraced the technique much more readily than Indians further contributed to variolation's more "European" appearance. ${ }^{92}$

As discussed above, there was some justification for distinguishing between the indigenous practice of variolation and the practice advanced by European surgeons. There is no point in denying that the colonial authorities introduced, changed and perhaps even improved the indigenous technique. Still, it is worth noting how they sought to mask its

\footnotetext{
${ }^{86}$ Ibid., fol. 108.

${ }^{87}$ TNSA, SGR vol. 1, fol. 194; BL-OIOC F/4/96, Board's Collections no. 1953, fol. 43.

${ }^{88}$ Proceedings of the Medical Board, 3 Apr. 1801, with enclosures entered in: TNSA, Madurai DR vol. 1181, fol 266. "Northern Brahmins" refers to the indigenous inoculators in the northern parts of the Presidency.
}

\footnotetext{
${ }^{89}$ TNSA, Coimbatore DR vol. 592, fol. 194.

${ }^{90}$ BL-OIOC F/4/96, Board's Collections no. 1953 , fol. 50 .

${ }^{91}$ Arnold, op. cit., note 5 above, pp. 127-8, 139.

${ }^{92}$ Proceedings of the Medical Board, 6 Apr. 1801, entered in: TNSA, Madurai DR vol. 1181, fol. 267.
} 


\section{Niels Brimnes}

indigenous roots and take as much credit for the diffusion of the practice as they could. Thus, in March 1801 Richardson wrote to the Medical Board:

I have pleasure to inform you that a pupil of mine Moresevary Pillai a Malabar man who practices the healing [art] in a village about fifteen Miles from hence, has commenced [as] inoculator for the Small pox[.] I knew nothing of this till he called at my house on the 16th Instant bringing with him his first patient Ramah Lingum[.] You may imagine the great satisfaction it gave me to have two such remarkable visitors under my roof, as the first Inoculator, and the first patient inoculated by a native to the south of the Kistna[.] I was the more pleased, because I might perhaps claim some merit as being instrumental in bringing this business to its present state ...93

It is quite likely that Moresevary had been instructed in variolation by Richardson, but it is still significant that Richardson presented the independent adoption of variolation by an Indian agent in terms of a teacher-pupil relation. The ambiguous roots of variolation compelled the medical establishment repeatedly to affirm that they controlled the practice and its diffusion throughout south India. We might in this repeated affirmation identify an attempt to "domesticate" a hybrid medical practice with muddled origins.

In what appears to have been the last public advertisement to promote variolation, the government in August 1802 published an abstract of inoculated persons that listed merely seven casualties out of more than 26,000 operations and then declared: "The Governor in Council actuated by motions of humanity and anxiety to promote the comfort and happiness of the Native inhabitants of this place, trusts that the above account cannot fail to convey to their minds a first impression of the beneficial consequences which result from the use of inoculation of the Small Pox". The government urged influential Indians to encourage variolation through their own example and to "explain the advantage attending the use of inoculation to the lower order of inhabitants whose situation in life may not afford to them the means of appreciating the benefits attending that practice". 94 After this straightforward endorsement of variolation, it was obviously going to be very difficult for the government publicly to reject variolation in favour of vaccination just six month later.

Yet, that was precisely what the colonial authorities had to do. The Medical Board suggested an advertisement modelled on one produced by the citizens of Manchester for the poorer inhabitants. The first sentence of this announcement established that the new vaccine was "a certain Preventative against the Small Pox" (emphasis in original). It continued with reflections more suited to the Christian audience in Manchester than a south Indian and overwhelmingly Hindu one, and then drew attention to the fact that "this late Gift from Heaven" was given "through the Medium of that highly favoured and long Venerated Animal, from which it takes its name". The Medical Board's proposed version ended by stating that vaccination was "greatly preferable" to variolation, because the resulting disease was milder and not contagious. ${ }^{95}$

The government did not adopt the Manchester declaration, but decided to refer more explicitly to the U-turn in the campaign against smallpox. An advertisement, published on 19 January 1803, began with an explicit reference to the earlier August 1802 promotion of

\footnotetext{
${ }^{93}$ Proceedings of the Medical Board, 6 Apr. 1801, with enclosures entered in: TNSA, Madurai DR vol. 1181, fols 268-9. "Malabar" means Tamil.
}

\footnotetext{
${ }^{94}$ TNSA, SGR vol. 13A, fols 445-8.

${ }^{95}$ BL-OIOC F/4/153, Board's Collections no. 2613, fols $50-3$.
} 


\section{Variolation, Vaccination and Popular Resistance in South India}

variolation, explaining that the Governor in Council deemed it proper "at this time to make known the considerations, under which it has been judged expedient to postpone the adoption of the measures explained in the above Advertisement". Then came a narrative of the efforts of the medical men in Europe to "ameliorate the condition of Human life". It stated that the cowpox vaccine not only made it possible entirely to avoid the effects of smallpox, it also promised to "explode" the disease forever. From a passage on the transfer of the vaccine from Europe to India, it clearly emerges that the British were acutely aware that they were now benevolently donating their discovery to other parts of the world in the campaign against a common and dreadful disease:

The same spirit of benevolence which guided the labours of these persons in Europe, led to the adoption of the means best calculated to convey the fruits of the happy discovery to India; and this humane object having been after much care effected the Inhabitants of India may, by following the example of the European Nations[,] be for ever freed from further apprehension or danger from the small pox. ${ }^{96}$

Moreover, the British now employed a more explicit universalistic language, which permitted them to see themselves as struggling on behalf of mankind against ignorance and superstition. In the advertisement they expressed the hope that "such inestimable benefit to mankind will be received with equal gratitude by the Inhabitants of India [as] it has been evinced by the Inhabitants of every other part of the World". ${ }^{97}$ In October 1804 the collector of Madurai in a locally published proclamation referred to "The benefit which has been experienced by all the world by an inoculation called the Cow Pox". At the same time the acting collector in Trichinopoly wrote to the Tondaiman Rajah of Pudukkottai:

You will no doubt have heard of the late important discovery of the vaccine Inoculation or Cow Pox a disease not only mild in its operation but a sure and Certain preventitive [sic] against the dreadful ravages Committed by the Natural small Pox among all Classes of People in every part of the World without distinction[.] ${ }^{98}$

Finally, when the collector of Madurai in 1806 requested local zamindars to donate a sum of money to Edward Jenner, he referred to "[t]he benefit which all the world has derived from the human attentions of Doctor Jenner". 99 By now, any ambiguity that might have attended the earlier advertisements on variolation had been thoroughly eliminated. Within a few years the colonial authorities had moved from promoting variolation with reference to its indigenous roots to promoting vaccination with reference to the benevolence and humanity of European medicine. The roles of colonizer and colonized were clearly and unambiguously defined: the people of India were to follow the European nations and express their gratitude to European medical benefactors.

However, a little more than a decade later, it seems as if it was less important to uphold a sharp distinction between indigenous practices and European medicine. In 1819 there was an incident which challenged the notion of vaccination as an exclusively European practice.

\footnotetext{
${ }^{96}$ Ibid., fols $69-75$ (another copy: fols 77-84).

${ }^{97}$ This was, however, followed by a more specific reference to the fact that the vaccine emanated "from a source sanctified by the several sacred Laws of their Hindoo Religion." Ibid., fols $73-4,82$.
} 


\section{Niels Brimnes}

In what might well have been a piece of conscious propaganda, evidence that vaccination had been known in ancient India, was published in the Madras Courier. Whether this was "a pious fraud" or not, it does not seem to have caused any disapproval within the colonial administration. ${ }^{100}$ Whereas the colonial authorities attempted to domesticate variolation from its indigenous context by detaching the practice from indigenous society, this was the reverse process: an attempt to attach vaccination to Indian tradition. ${ }^{101}$

Similarly, as variolation never became a serious rival to vaccination in the Madras Presidency, it was not necessary to demonize it. In 1830 Whitelaw Ainslie, who was renowned for his sympathetic attitude to Indian medicine, wrote about variolation in relatively positive terms. Although he found vaccination far superior, variolation had enough advantages to make indigenous reluctance to accept the new practice understandable: "In the pure habits of the Hindus it may easily be imagined that the inoculated smallpox is almost constantly benign; and this mildness, together with the simplicity of the operation, added no doubt to the powerful influence of custom for centuries, made the inhabitants of India not a little reluctant to the introduction of vaccination". ${ }^{102}$ Thus, it seems that the rather sudden shift from variolation to vaccination created a conjuncture in which it was particularly important to the British to insist on the "difference" between indigenous medical practice and benevolent European medicine. Before the shift, this was not possible, and a few decades later it was less important.

\section{The Indigenous Agent}

If, after the introduction of the cowpox vaccine, the situation was unambiguously conceptualized by the colonizers as one of European benevolent medicine versus indigenous prejudice and superstition, there was still one important area in which this simple opposition was not immediately applicable: the British needed native agents to perform the vast majority of vaccinations if the campaign were to have even a tiny impact on the occurrence of smallpox throughout the districts of the Madras Presidency. In other words, the British needed to come to terms with "the native vaccinator" in a way that separated him from what they conceived of as the mass of ignorant and superstitious Indians. ${ }^{103}$

When the government launched the campaign to promote variolation in September 1800, it did not explicitly contemplate whether and how native inoculators were to be used.

\footnotetext{
${ }^{100}$ Wujastyk, op. cit., note 19 above. Also in the early decades of the nineteenth century, the British surgeon Thomas Coats in Poona composed a pamphlet, written in Marathi and in keeping with regional cultural idioms, which aimed to convince Indians of the benefits of vaccination. Coats did not, however, claim that vaccination had been known in India, but gave full credit to Jenner. Guha, op. cit., note 11 above, pp. 140-55.

${ }^{101}$ The claim that vaccination was known in ancient India was of course consistent with the general "orientalist" —and later also nationalist-notions that located any scientific rationality which the Indians might have possessed in a remote golden age. See,
}

for instance, Prakash, op. cit., note 6 above, pp. 86-117, 230. For a comparable attempt to locate scientific astronomy in ancient India, see ibid., pp. 71-2.

${ }^{102}$ Ainslie, op. cit., note 8 above, p. 64. The attitude towards variolation was different in Bengal where it represented a mightier rival to vaccination. A report from 1850 depicted variolation as "a murderous trade" Arnold, op. cit., note 5 above, p. 138.

${ }^{103}$ I have dealt with this issue more generally in 'Coming to terms with the native practitionerindigenous doctors in colonial service in South India 1800-1825', in S Bhattacharya (ed.), Imperialism, medicine and South Asia: a socio-political perspective, 1800-1950, Delhi, Orient Longman (forthcoming). 


\section{Variolation, Vaccination and Popular Resistance in South India}

Indians willing to be inoculated were told to avail themselves of the gratis assistance of Company surgeons, and consequently the efforts were halted when medical officers were occupied with more pressing duties. ${ }^{104}$ The issue of how to relate to native inoculators came, however, immediately to the fore. As early as November 1800, the collector in Coimbatore assumed that European surgeons would instruct Indian doctors in variolation, and a month later he submitted a village headman "with the reputation of being Doctor" to the surgeon for instruction. ${ }^{105}$ Also in November 1800, the collector of Guntur District suggested that European surgeons should instruct Indian inoculators. ${ }^{106}$ In the first season of the campaign almost half of the 475 registered inoculations were performed by two native inoculators: Runga Das, working under the Head Surgeon in Madras, and Moresevary Pillai, who was placed under the surveillance of Richardson in Trichinopoly. ${ }^{107}$ In April 1801, the government supported the encouragement of a "few Brahmin Doctors in each district to become practitioners of variolation" and in December that year the government decided to reward indigenous inoculators with 20 pagodas (approximately 70 rupees) for every hundred successful operations. ${ }^{108}$ At this point Indians were probably employed as inoculators at several stations. Richardson described Moresevary Pillai as the first Indian inoculator south of the river Krishna in March 1801, and in December that year the government referred to several Indian inoculators working under Richardson's direction. Similarly, the collector in Tanjore sent the first four Indians to Richardson for instruction in September $1801 .^{109}$

Thus, when the cowpox vaccine reached Madras in 1802, a model for engagement with indigenous agents was already established. This envisaged the indigenous agent as an enterprising individual, who was rewarded according to his endeavours. Other models were, however, put forward. Before December 1801 Indian inoculators were employed on a fixed salary and in both 1801 and 1802 collectors suggested combining a fixed salary with a reward. The Collector of Trichinopoly argued that while the reward would ensure the efficiency of the inoculators, the fixed salary would ensure that they worked conscientiously. ${ }^{110}$ Despite these alternatives, the plan for the diffusion of vaccination from January 1803 upheld the model based entirely on rewards, and the notion of self-interested indigenous entrepreneurs was central to the plan. Indian vaccinators were to be instructed by Company surgeons and, when sufficiently prepared, to receive a certificate without which they were not authorized to perform vaccinations. The reward was, however, halved to

${ }^{104}$ See the "circular advertisement" from Guntur, dated 27 Nov. 1800. BL-OIOC F/4/96, Board's Collections no. 1953 , fols $44-5$. For the problem of attending to other duties, see fols 75-6.

${ }^{105}$ TNSA, Coimbatore DR vol. 592, fols $89,103$. The letter assuming that indigenous doctors would be instructed is also included in BL-OIOC F/4/96, Board's Collections no. 1953, fol. 36, but gives the collector in Salem as author.

${ }^{106}$ BL-OIOC F/4/96, Board's Collections no. 1953, fols 43, 62 .

${ }^{107}$ Proceedings of the Medical Board, 6 Apr. 1801, entered in: TNSA, Madurai DR vol. 1181, fol. 267-8.
${ }^{108}$ Letter from the government to the Board of Revenue, dated 3 Apr. 1801, entered in: TNSA, Madurai DR vol. 1181, fol 265. Government proclamation, 21 Dec. 1801, entered in: TNSA, Madurai DR vol. 1182, fols 443-4.

${ }^{109}$ Proceedings of the Medical Board, 6 Apr. 1801, with enclosures entered in: TNSA, Madurai DR vol. 1181, fols 268-9. Government proclamation, 21 Dec. 1801, entered in: TNSA, Madurai DR vol. 1182, fols 443-4. TNSA, Tanjore DR, vol. 3207, fols 51-5.

${ }^{110}$ TNSA, Trichinopoly DR vol. 3661, fols 158-9. In 1801 the collector of Coimbatore argued along similar lines. TNSA, Coimbatore DR vol. 592, fol. 194. 


\section{Niels Brimnes}

10 Pagodas for every hundred vaccinations and it was emphasized that vaccinators were subject to strict control by superior medical officers. ${ }^{111}$

Some indigenous agents represented genuine success stories and were highly praised by the colonial authorities. Among those were Moresevary Pillai and Sawmy Naik. In the early stages of the campaign, Moresevary Pillai was paid twice as much as other inoculators "as a reward for his exertions in the cause of humanity", while Sawmy Naik became Chief Native vaccinator with a salary equivalent to that of surgeons serving at civil stations. ${ }^{112}$ These individual successes apart, the indigenous vaccinator soon became a target of criticism. When the reward system had operated for a little more than a year, the Medical Board noted that the vaccinators tended to vaccinate only in the vicinity of their home villages. The Board then suggested that the vaccinators receive an additional fixed salary so that they might see themselves "more in the light of Company Servants" and also be liable to be placed wherever the Company surgeons decided. ${ }^{113}$

However, the Medical Board realized the shortcomings of their mode of engaging with Indian vaccinators too late. In November 1804, Alexander Mackenzie submitted a letter to Bentinck, the Governor, in which he criticized the reward system and challenged the implicit view of the indigenous agent. Mackenzie noted that the trust put in the Indian vaccinators-whom he believed were mainly from "inferior Classes" — was so great and the means of control so inadequate, that in most areas the system depended entirely on their activity and zeal. The system of paying the native vaccinators according to the number of persons vaccinated only encouraged carelessness, as they were likely to consider their private advantage and pay attention only to the numbers treated, not bothering to check whether their patients actually caught the vaccine disease. Mackenzie's suggestion to remove this obstacle was surprisingly simple: if the native vaccinators were paid a regular salary, " $[\mathrm{t}]$ hey will perform their duties on the fixed Principles of obedience and zeal having no temptations to dishonesty they will direct their attention to the proper object of their Employment". 114

The Medical Board reacted passionately to the attack on the system developed under its guidance. They questioned Mackenzie's motives and noted that he did not have any experience in vaccination. Emphasizing the universal nature of mankind, they also challenged his perception of the Indian vaccinator:

It is observed by Mr. Mackenzie that native practitioners cannot divest themselves of all considerations of private advantage it would indeed be very extraordinary if they were not actuated by the same motives that operate so powerfully on mankind in general but the conclusions, the Medical Board would draw from this are very different from those of Mr. Mackenzie for instead of being productive of fraud self interest if properly understood will afford the best security against it, or even irregularities by which they would be liable to lose a respectable situation and comfortable subsistance $[$ sic $][.]^{115}$

${ }^{111}$ BL-OIOC F/4/153, Board's Collections no. 2613 , fols $42-3,60-3$.

${ }^{112}$ On Moresevary Pillai, see TNSA, Trichinopoly DR vol. 3643, fol. 60. On Sawmy Naik, see Indian Medical Gazette, op. cit., note 59 above; BL-OIOC F/4/153, Board's Collection no. 2613, fol. 108; BL-OIOC P/322/4, Madras Judicial Proceedings, 14 Dec. 1805, fol. 2439.

\footnotetext{
${ }^{113}$ Proceedings of the Medical Board, 21 May 1804, entered in: TNSA, Madurai DR vol. 1190, fols $152-3$.

${ }^{114}$ BL-OIOC P/255/43 MMP, 21 Dec. 1804, fols $6404-15$, quoted from fol. 6411.

${ }^{115}$ Ibid., fols $6390-91$.
} 


\section{Variolation, Vaccination and Popular Resistance in South India}

Bentinck was, however, not satisfied and ordered the Medical Board to present a more substantial response to Mackenzie's criticism. The Board then submitted their objections and remarks in the form of a number of queries, which Mackenzie answered in March 1805. ${ }^{116}$ Here he maintained his view of the Indian vaccinator and declared: "that the natives of the lower Classes to whom vaccination is confided, are in general careless, ignorant, and dishonest, but that the present system by offering premiums unrestricted by effective checks to all persons of that description who may offer their services exposses [sic] the Public to great deception and frauds". ${ }^{117}$ He also maintained that the transformation of the Indian vaccinator was easily attainable: if they were paid a regular salary, they would feel obliged to perform their duties properly. ${ }^{118}$ Mackenzie had by now won over the second member of the Medical Board, Terence Gahagan, but the two other members remained hostile. They dismissed the allegation that Indian vaccinators were recruited from the lower orders of Indian society and submitted a list of certified vaccinators from which, they claimed, "it will appear, that these Practitioners are very properly of the highest and of all Casts, and not uninstructed as Mr. Mackenzie has asserted". ${ }^{119}$ The list contained the names of 66 certified Indian vaccinators, but it does not provide a very precise indication of their status in Indian society. There was only one low-caste Paraiyan inoculator, employed in the town of Madras, while there were ten Brahmans, employed mainly in the southern part of the Presidency. The vast majority of the inoculators, however, were entered as either "Gentoos" (Telugus) or "Malabars" (Tamils) and these terms were linguistic designations covering a wide range of castes with very different status (see Table 3). ${ }^{120}$ The Medical Board also dismissed Mackenzie's argument that there was not sufficient control of the vaccinators. They were subject to the supervision of both surgeons and collectors and obliged to submit monthly registers of vaccinated persons countersigned by village headmen. These measures, the Board argued, were "as effectual a check against abuse as at the present juncture can perhaps be established". ${ }^{121}$

While Mackenzie's plan was still pending, a number of proposals for amendments to the system of vaccination were submitted to the Board. J A Dubois initially presented his proposal in a letter of 15 March 1805 addressed to the superintending surgeon of the southern division of the army. For Dubois the major problem was the lack of control of the Indian vaccinators: "One of the most common irregularities among the Native practitioners who are not under a strict control, is to run incessantly from one village to another to find patients without visiting afterwards the persons under infection, nor paying otherwise the least attention to them." 122 The central elements in Dubois' proposal were that the vaccinators ought to be paid a regular salary and that the responsibility to oversee their practice be given to the collector and the tahsildars employed under him. ${ }^{123}$ In a later communication to James Anderson, Dubois similarly suggested that vaccinators should be employed in each talook (district sub-division) under the immediate superintendence of the tahsildars, and it does seem that Dubois had considerably more trust in indigenous

\footnotetext{
${ }^{116}$ Ibid., fols 6385-90. BL-OIOC P/255/53

MMP, 19 June 1805 , fol. 3976.

${ }^{117}$ BL-OIOC P/255/53 MMP, 19 June 1805, fol. 3999 .

${ }^{118}$ Ibid., fol. 4001.

${ }^{119}$ Ibid., fols 3983-4.
}

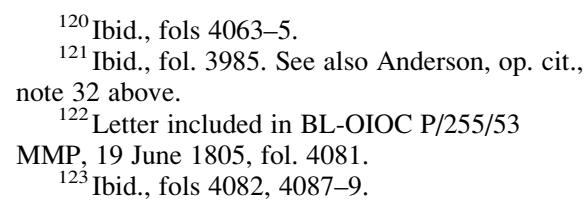




\section{Niels Brimnes}

revenue officers than he had in vaccinators. Despite the fact that Dubois' proposals were in line with Mackenzie's, Anderson appeared more ready to consider changes in the system, arguing that "one mode or system will not answer equally for all parts of the country; and therefore it seems advisable to attend to the proposals of persons of local residence". ${ }^{24}$

Also in April 1805, Surgeon J Dalton wrote to the government suggesting that Indian vaccinators be put on a permanent salary in a quite different way. He began with a description of the village "establishment":

Your Lordship, knows that the Country is divided, into, Districts, Talooks and Villages, and that certain proportions of the Crops, are allowed, towards carrying on religious ceremonies towards burning the Dead, and towards the Police \&ca \&ca. I therefore humbly submit, that vaccination shall form apart [sic] of the establishment thus provided for in a proportionate Ratio with people of the above description, as the extent of the Talook, or Village May be; And, that carrying on vaccination, and keeping up the Disease, shall be the tenure, by which they, and their Successors Shall hold the land, that may be granted them by Government ... ${ }^{125}$

Dalton simply suggested that the inoculator should be transformed from an entrepreneur into a village servant; rewarded neither in relation to the number of people vaccinated nor by a fixed salary but by rights in land and claims to a share in the village produce. He envisaged that the office of village inoculator would be transmitted from father to son and believed that "the station of permanent vaccinators" would "induce numberless candidates . . . to present themselves". 126

Finally, in May, William Horsman, superintendent of the vaccine establishment, and likely to lose his position to Mackenzie if the latter's plan was adopted, tried to incorporate the criticism in a plan for gradual changes to the system. As a genuine compromise, Horsman suggested that the reward be halved to 5 pagodas per 100 vaccinations and supplemented by a low fixed salary. This system was to apply until the "superstitious prejudices" among the Indians had dissolved and the duty of vaccination could-as suggested by Dalton-be the responsibility of the "Village Doctors". This system would, Horsman argued, be cheaper than the present. It would retain "the essentially necessary incitement to industry" and at the same time turn the vaccinators into government servants and thus liable to be transferred from area to area according to orders from superintending surgeons. $^{127}$

Lord William Bentinck was not, however, a man of compromises and on 18 June he delivered a minute which cut through the discussions and established the system proposed by Mackenzie, arguing that the successful vaccination of the population in the Madras Presidency was an undertaking that demanded time, caution and perseverance "in a well arranged system". ${ }^{128}$ Moreover, the Medical Board suffered the indignity of being stripped of the responsibility for vaccination. Bentinck put his faith in the judicial system, which was still being established, and ordered that each zillah (judicial district) get its own department

\footnotetext{
${ }^{124}$ Asiatic Annual Register, 1805, Chronicle, pp. 1-4, quoted from p. 3 .

${ }^{125}$ Letter included in BL-OIOC $\mathrm{P} / 255 / 53$

MMP, 19 June 1805, fols 4093-4.

${ }^{126}$ Ibid., fols 4094-5. As pre-colonial immunizers seem to have been itinerant groups,
}

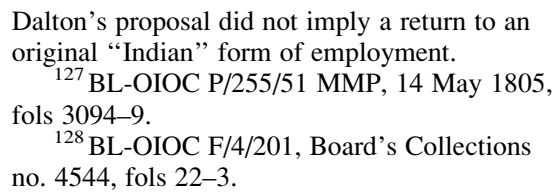




\section{Variolation, Vaccination and Popular Resistance in South India}

of vaccination consisting of four native inoculators paid 4-5 pagodas a month and superintended by the European surgeon attached to the Zillah Court. Mackenzie was appointed superintendent of vaccination, reporting directly to the government via the judicial department. ${ }^{129}$ In London, the Court of Directors approved the steps taken by Bentinck, but they could not accept that the expertise of the Medical Board was to be bypassed in matters relating to vaccination and ordered that Mackenzie report to the government through the Medical Board. ${ }^{130}$

From the position of superintendent of vaccination, Mackenzie in the following years had a rich opportunity not only to propagate the virtues of "his" system, but also to represent the Indian vaccinator and evaluate his services to the diffusion of vaccination among the Indian population. Although Mackenzie stressed that he had employed more vaccinators for less money, the number of vaccinated did not - in the first year at least—match the rise in the number of vaccinators. In October 1806 Mackenzie described the achievements under the new system as "satisfactory", but he clearly felt obliged to state that vaccination was now conducted under different principles:

The Native Vaccinators at present act under a regular plan calculated to diffuse vaccination gradually among the people: but those formerly employed were rather encourged [sic] to practice abuses than to exert their endeavours for the advancement of this object ... instead of employing Natives of all descriptions upon absurd allowances in propagating Vaccination; a few persons regularly instructed are maintained upon moderate Salaries. ${ }^{131}$

A year later Mackenzie also emphasized how the Indian vaccinators worked "under a regular plan calculated to diffuse vaccination gradually", that they acted on "the principle of duty, zeal and emulation", and that they were now "vigilantly inspected by the superintendent". ${ }^{132}$ According to Mackenzie, the indigenous agent was now employed in a bureaucratic context and he was no longer careless, ignorant or dishonest, but a zealous civil servant on regular pay.

For the present discussion the important point in the debate between the Medical Board and Mackenzie about the nature of the indigenous agents serving the campaign against smallpox, is that these vaccinators simply had to be exempted from the prejudice ascribed to the Indians in general and conceded a middle position between the indigenous population and their European benefactors. While the Board believed that they could be elevated to this position through stimulation of their self-interest, Mackenzie envisaged them as zealous, bureaucratic servants. In both cases, however, they were capable of serving as central figures in the colonial campaign against smallpox.

\section{Concluding Remarks}

In south India the campaign against smallpox began in 1800 as a campaign to promote variolation — which was virtually unknown in the Madras Presidency-but it was abruptly redirected towards the promotion of vaccination in January 1803. The shift in preventive

\footnotetext{
${ }^{129}$ Ibid., fols 4, 31, 49.

${ }^{130}$ BL-OIOC F/4/268, Board's Collections no. 5891 , fols $77-80$.
} 


\section{Niels Brimnes}

technique might not have appeared great to the indigenous population: both variolation and vaccination used arm-to-arm technology, while vaccination was probably accompanied by less therapeutic interventions than variolation. Neither was the identifiable pattern of popular resistance towards the two techniques significantly different. The pattern of resistance to both variolation and vaccination appears to have been varied and largely determined by specific, local conditions.

The colonial authorities tended, however, to generalize popular resistance as prejudice, superstition and an ingrained aversion to change in Indian society. While this rhetoric fitted well into a more general attempt to construct Indian "otherness" inherent in the development of colonial hegemony, it is possible to identify profound ambiguities in the rhetoric about indigenous prejudice accompanying the campaign against smallpox. Although they attempted to "domesticate" variolation, the colonial authorities were unable to ignore the indigenous roots of the technique. Only after the introduction of vaccination was it possible to construct the campaign against smallpox unequivocally as European medical benevolence against indigenous prejudice and superstition. Similarly, the colonial authorities needed reliable indigenous agents as the backbone of the campaign and although these were much criticised they were always seen as transformable into valuable servants of colonial medicine. These aspects of the conceptualization of Indian society illustrate that even when colonial power and European medicine joined forces in the construction of an irrational and superstitious "other", ambiguity could not be eliminated. 